\title{
Лазерный диодный модуль высокой энергетической яркости с волоконно- оптическим выводом ЛМД-50
}

\author{
Д.А. Автайкин, Е.В. Борисов, В.А. Великанов, И.В. Галушка, А.В. Кузнечихин, \\ Г.Т. Микаелян, В.А. Панарин, С.Н. Соколов", Т.Д. Токарева \\ ООО "НПП "Инжект", Саратов \\ "E-mail: s.sokolov@nppinject.ru
}

DOI: 10.31868/RFL2020.164-165

Представлены результаты разработки диодного лазерного модуля высокой энергетической яркости с волоконно-оптическим выводом для накачки волоконных лазеров.

В последнее десятилетие наблюдается бурный прогресс в материалах, конструкциях и технологиях производства диодных лазеров. Мировой выпуск диодных лазеров типов стабильно превышает 40\% (6,9846 млрд. долл. США) в объеме производства лазеров всех типов в 2019г. [1]. Наибольшее применение высокомощные диодные лазеры находят в секторе рынка лазерных технологических установок для обработки материалов, системах накачки волоконных и твердотельных лазеров. В этой связи создание мощных высокоэффективных диодных лазерных модулей является приоритетной задачей. В ООО "НПП "Инжект был разработан лазерный диодный модуль ЛМД-50 и начато его производство. В процессе разработки этого модуля была создана топология и технология изготовления активного элемента - лазерного диода и прецизионной сборки модуля. Была спроектирована оптическая схема вывода излучения из корпуса модуля и изготовлены оптические микро-линзовые элементы, обеспечивающие достижение выходной мощности лазерного излучения 50 Вт в непрерывном режиме в сердцевине световода с диаметром 105 мкм с числовой апертурой 0,22 . Габаритные размеры корпуса модуля составляют: 78(Д)х28(Ш)х13,5(В) мм. Внешний вид модуля приведен на фотографии Рис.1.

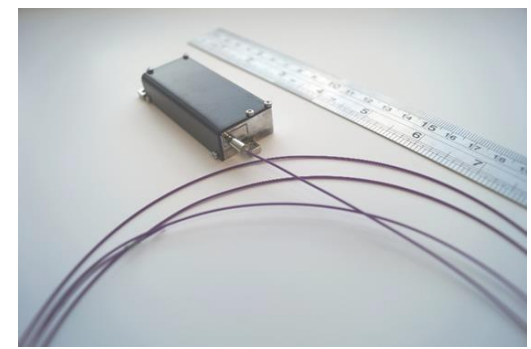

Рис.1. Внешний вид лазерного диодного модуля ЛМД-50.

Основные параметры лазерного диодного модуля приведены ниже в таблице 1. 
Таблица 1

\begin{tabular}{|l|c|c|c|c|}
\hline \multicolumn{1}{|c|}{ Параметр } & $\begin{array}{c}\text { Единицы } \\
\text { измерения }\end{array}$ & Мин. & Ном. & Макс. \\
\hline Мощность лазерного излучения & Вт & 44 & 50 & 54 \\
\hline Длина волны лазерного излучения & нм & 973 & 976 & 979 \\
\hline $\begin{array}{l}\text { Полуширина спектра лазерного } \\
\text { изучения (FWНМ) }\end{array}$ & $\mathrm{Hм}$ & 4 & 5 & 6 \\
\hline $\begin{array}{l}\text { Температурный сдвиг длины волны } \\
\text { лазерного излучения }\end{array}$ & $\mathrm{Hм} /{ }^{\circ} \mathrm{C}$ & & 0,35 & \\
\hline $\begin{array}{l}\text { Сдвиг длины волны лазерного } \\
\text { излучения от тока }\end{array}$ & $\mathrm{Hм} / \mathrm{A}$ & & 0,9 & \\
\hline КПД & $\%$ & & 46 & \\
\hline Рабочий ток, & $\mathrm{A}$ & & 12 & \\
\hline Пороговый ток, & $\mathrm{A}$ & & 0,6 & \\
\hline Рабочее напряжение, & $\mathrm{V}$ & & 9 & \\
\hline Дифференциальная эффективность & $\mathrm{BT} / \mathrm{A}$ & & 6,5 & \\
\hline Диаметр защитного покрытия \\
световода - тефлон (ЕТҒЕ), мкм & мкм & & 900 & \\
\hline
\end{tabular}

Анализ конструкций лазерных диодных модулей с волоконно-оптическим выводом, выпускаемых зарубежными фирмами: Jenoptik, DILAS/Coherent, II-VI, Lumentum, Suzhou Everbright Photonics, Jilin Province Changguang Rays Laser Technology, BWT Beijing, показал, что только фирма DILAS/Coherent выпускается ЛД модуль с такой же номинальной выходной мощностью 50 Вт, удобной для ряда применений. ЛМД-50 модуль имеет длину волны лазерного излучения 976+/-3 нм оптимальную для накачки волоконных лазеров. По основным техническим параметрам лазерный диодный (ЛД) модуль высокой энергетической яркости с волоконно-оптическим выводом ЛМД-50 соответствует зарубежному аналогу. В конструкции ЛД модуля ЛМД-50 использованы материалы, изготовленные в России, поэтому применение модулей в новых отечественных разработках волоконных лазеров и лазерных приборов устраняет необходимость импорта, зависимость от монопольного поставщика и отрывает новые возможности создания отечественных волоконных лазеров.

Лазерный диодный модуль предназначен для использования в качестве источника мощного оптического излучения и имеет хорошие перспективы использования в аппаратуре широкого применения в системах диодной накачки волоконных лазеров; лазерной микрообработке материалов; медицинских приборах и научных исследованиях.

\section{Литература}

[1] Annual Laser Market Review \& Forecast 2020: Laser markets navigate turbulent times, Jan 28th, 2020; Электронный $\quad$ pecypc: URL: https://www.laserfocusworld.com/laserssources/article/14073907/laser-markets-navigate-turbulent-times (дата обращения: 10.07.2020). 